\title{
An Empirical Analysis of Agglomeration Effects on the Location Choice of Japanese Electronics Firms in China Using Provincial Data
}

\author{
Suminori TOKUNAGA* and Shaosheng JIN**
}

\begin{abstract}
In this paper, we examine the hypothesis that agglomeration has an important effect on the location choice of Japanese electronics firms in China in line with Krugman [18], Fujita and Krugman [6], Fujita, Krugman, and Venables [7] (new economic geography, in short NEG). Using the data from Cyugoku Sinsyutsu Kigyou Ichiran 2003-2004 (Japanese enterprise investments in China 2003-2004), we estimated a location choice model of Japanese electronics firms with market potential, industrial agglomeration and traditional factors such as wage, infrastructure and policy incentives as explanatory variables. The results of this estimation showd that the agglomeration effects play an important role in choices for location of Japanese electronics firms in China.
\end{abstract}

LEL classification : F23, R30, O53

Keywords: Agglomeration Effects, China, Japanese Electronics Firms, Labor Cost, Location Choice, Market Potential, NEG Model, Negative Binomial Model

\section{Introduction}

Japanese Foreign Direct Investment (FDI) in electronics industry in East Asia has been increasing for the last two decades, especially since the yen appreciation following the Plaza Accord in 1985. In China, Japanese FDI has been increasing since its open door policy in 1978 with remarkable peaks in the 1992-95 and 1999-2001 periods. With this as a trigger, many studies have been conducted to understand the factors that determine location choices of FDI activities using some traditional factors, such as market size, labor cost, and government policies [e.g. Zhang [29], Broadman and Sun [2], Cheng and Kwan [3], Sun et al. [23]].

Since the 1990s however, some new insights on agglomeration economies have been provided by the new research area known as new economic geography (hereafter, we use NEG) which follows the works of Krugman [18], Fujita and Krugman [6], Fujita, Krugman, and Venables [7], Hanson [11], and Fujita and Thisse [8]. In the location choice model of multinational corporations, agglomeration effect or agglomeration economy occurs because firms seek to overcome information asymmetry and business uncertainties in their host countries. Such a model has been employed by Smith and Florida [22] and Head et al. [15], [16] to understand the relationship between

* Professor, Department of Appropriate Technology and Science for Sustainable Development, Graduate School of Life and Environmental Sciences, University of Tsukuba, 1-1-1 Tennodai, Tsukuba, Ibaraki, 305-8572, Japan E-mail : stokuna@sakura.cc.tsukuba.ac.jp

** Graduate student, Department of Appropriate Technology and Science for Sustainable Development, Graduate School of Life and Environmental Sciences, University of Tsukuba

Received: 29 May 2006 Accepted: 17 December 2006

(C) 日本地域学会 (JSRSAI) 2007 
agglomeration effects and location choice of firm. Tokunaga and Ishii [26], [27] studied the factor of location choice for nine Japanese electronics firms in East Asia and found that the industry-level agglomeration had a positive effect on location choice for 1986 to 92 period. Similarly, Tokunaga and Akune [25] found that industry-level agglomeration played an important role in location choice of Japanese electronics industry for 1985 to 1999 period in East Asia. In all these models however, agglomeration effect is simply measured by the total number of foreignfunded enterprises in a country. Here, this model is extended to incorporate advances introduced Tokunaga and Akune [25] with Head et al. [16] and Chyau and $\mathrm{Ng}$ [4] $]^{1}$.

Thus, the objective of this paper is to explore the factors guiding the new location choice of Japanese electronics firms in China. Using the provincial and firm-level panel data of Japanese electronics FDI in China from 1992 to 2003, we estimate a location choice model of Japanese electronics firms in China.

The organization of this paper is as follows. In section 2, we investigate features of the Japanese investment in the electronics industry in China. Section 3 presents our model and the data, including the provincial market potential variable. Section 4 presents the estimation results. We conclude with a summary of the major results in the final section.

\section{Geographic Distribution and Location Determinants of Japanese}

\section{Electronics Firms in China}

Japanese electronics FDI has been increasing since its open door policy in 1978 with remarkable peaks in the 1992-95 and 1999-2001 periods as shown in Figure 1 $^{2}$. In 1992 the Chinese Premier, Mr. Deng Xiaoping, during his tour to the south reconfirmed China's determination to establish the Socialist-market economy as a national policy. This became a landmark for the reform and opening up policy. Second, as China entered into World Trade Organization (WTO) from 2001, there was the other small boom of Japanese FDI in China. Furthermore, as shown in Figure 2, Japanese electronics FDI is highly correlated with the exchange rate between Japanese Yen and Chinese Yuan. After the Plaza Accord in 1985, Japanese electronics industry began overseas production in China. Since yuan was devaluated against the dollar due to the dollar pegging policy of yuan (8.7 yuan/dollar) in 1994, this increased the competitiveness of Chinese exports relative to Japan and hence the attraction of Chinese market for Japanese electronics industry.

Next, we survey about geographic distribution of Japanese electronics FDI in China. As can be seen, Figure 2 shows that many Japanese electronics firms locate in coastal provinces such as Shanghai, Jiangsu, Guangdong, Tianjin, Beijing, Fujian, and Liaoning. Furthermore, we calculate two location quotients (LQ) in Table 1 in order to analyze the spatial patterns of Japanese electronics manufactures in the Chinese province in more detail. Japanese Location Quotient 1

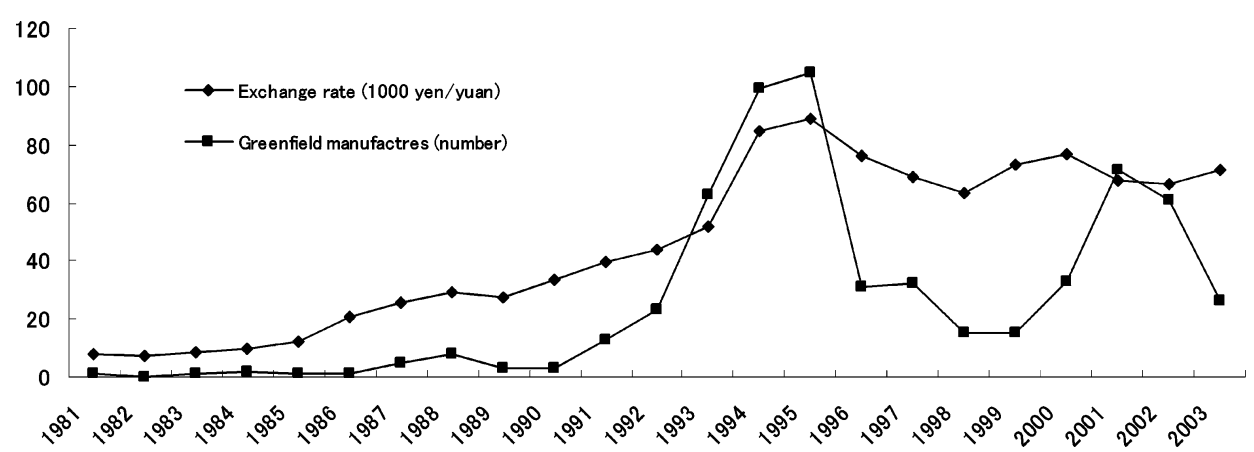

Figure 1. Japanese electronics FDI in China and Exchange Rate (1981-2003) 


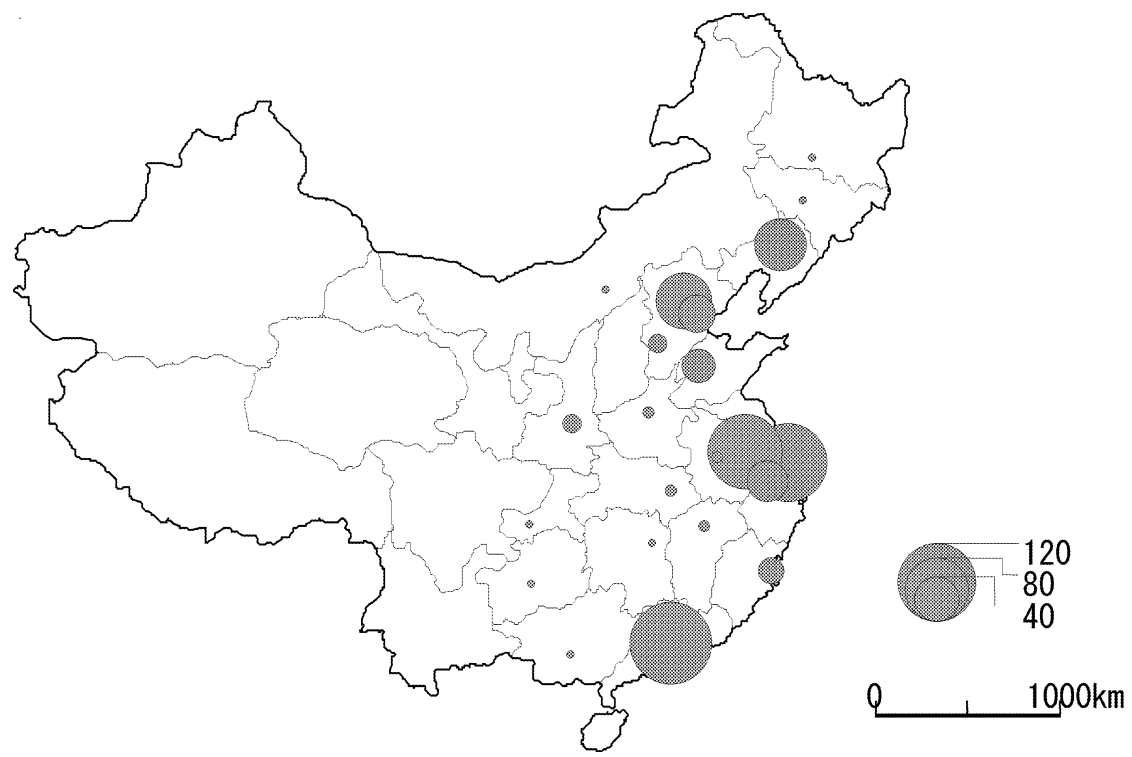

Figure 2. Spatial distribution of new plants for Japanese electronics manufactures in China from 1992 to 2003

Table 1 Location quotients of Japanese Electricity Industry Investment in China

\begin{tabular}{l|c|c}
\hline & LQJ1 & LQJ2 \\
\hline Beijing & 1.74 & 1.43 \\
Tianjin & 1.04 & 0.78 \\
Hebei & 0.49 & 0.70 \\
Inner Mongolia & 0.29 & 0.50 \\
Liaoning & 2.00 & 1.05 \\
Jilin & 0.16 & 0.31 \\
Heilongjiang & 0.11 & 0.27 \\
Shanghai & 2.36 & 0.65 \\
Jiangsu & 1.35 & 1.25 \\
Zhejiang & 0.54 & 1.09 \\
Anhui & 0.27 & 0.77 \\
Fujian & 0.48 & 1.18 \\
Jiangxi & 0.21 & 1.22 \\
Shandong & 0.87 & 0.62 \\
Henan & 0.20 & 0.57 \\
Hubei & 0.25 & 0.95 \\
Hunan & 0.06 & 0.50 \\
Guangdong & 1.05 & 1.86 \\
Guangxi & 0.15 & 0.79 \\
Chongqing & 0.23 & 0.25 \\
Guizhou & 0.35 & 0.99 \\
Shaanxi & 0.53 & 1.74 \\
\hline
\end{tabular}

Note: Japanese Location Quotient $1(\mathrm{LQJ} 1)=$ provincial percentage of Japanese electronics manufacturers/provincial percentage of all electronics manufactures

Japanese Location Quotient 2 (LQJ2) = provincial percentage of Japanese electronics manufacturers/provincial percentage of all Japanese manufactures 


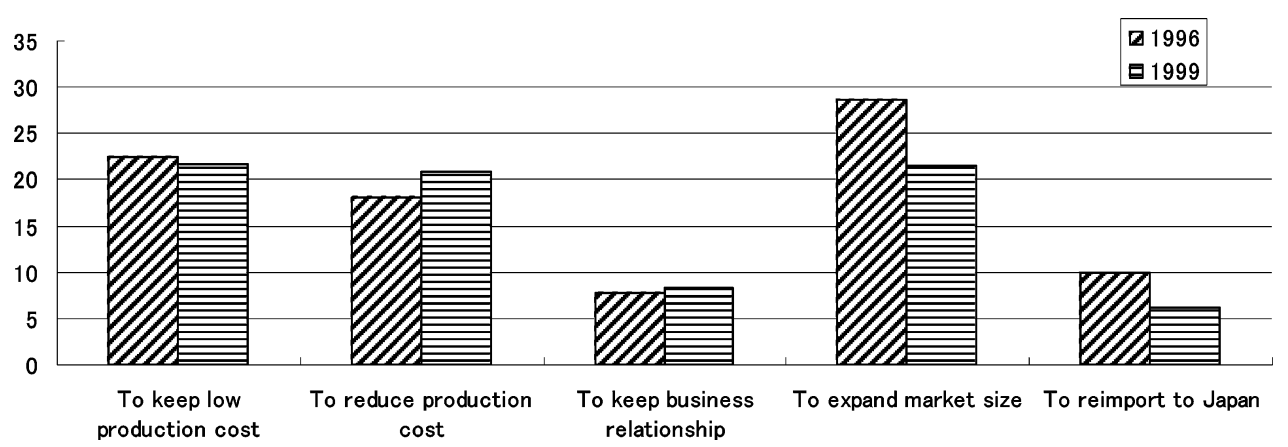

Figure 3. Motivations of Japanese electronics industry investment in China

Source: Basic Survey of Foreign Business Activity, NO. 6 and NO. 7, by the Ministry of Economy, Trade and Industry (METI), Japan.

(LQJ1) is defined as provincial share of Japanese electronics manufacturers divided by provincial share of all electronics manufactures. Japanese Location Quotient 2 (LQJ2) is also defined as provincial percentage of Japanese electronics manufacturers is divided by provincial percentage of all Japanese manufactures. According to this LQJ1, Shanghai is 2.36, Liaoning is 2.00, Beijing is 1.74, Jiangsu is 1.35 , Guangdong is 1.05 , and Tianjin is 1.04. Japanese electronics manufactures favor Shanghai, Liaoning and Beijing. Among Japanese manufactures, the highest share of the electronics manufactures is Guangdong according to LQJ2. As mentioned above, the coastal provinces have been the most favorable locations for Japanese electronics manufactures.

Next question is motivations of FDI for Japanese electronics industry in China. That is, what are the location determinants of Japanese electronics firms in China? To understand this, we consider survey data. According to the results from the surveys for foreign business activity of Japanese firms conducted by the Ministry of Economy, Trade and Industry (METI) in Japan, the main motivations of Japanese electricity industry investment in China are to (i) expand market size, (ii) keep low production cost, (iii) reduce production cost, and (iv) keep business relationship as shown in Figure 3. Thus, we can adopt the important location factors of (1) the local market of their products, and (2) labor cost. Furthermore, we can adopt an important factor of (3) good economic environments for Japanese firms in China. Finally, we can adopt the most important location factor of (4) agglomeration effect in order to test the hypothesis that industrial agglomeration plays an important role in location choice behavior of Japanese electronics firms in China as above mentioned.

\section{A Model of Location choice and Model Specification}

\subsection{Model}

Recent empirical studies of Japanese firm location focused on agglomeration economy in East Asia and China include Fukao and Yue [9], Togo and Arikawa [24], Belderbos and Carree [1], He [13], Tokunaga and Akune [25], and Wakasugi [28]. Fukao and Yue [9] found that localization economies had a positive effect and urbanization economies had a negative effect on location choice behavior of the Japanese electronics industry and Togo and Arikawa [24] found that agglomeration and industrial estate had a positive effect on location decisions in the Malaysian electronics industry. In China, He [13] found that agglomeration economies derived from the clustering of manufacturing and foreign investment activities influenced the location of foreign manufacturers. These studies indicate the importance of agglomeration economies in location choice. Thus, we would like to extend these results by looking in more detail. Wakasugi [28] found that factors related to human resources are more important than the 'hard' factors in attracting foreign firms 
to invest in China, using conditional logit model.

We model the location decision of Japanese manufacturing as a negative binomial model. First, we assume that a rational Japanese manufacturer $i$ would choose a Chinese province $j$ for its branch only if this firm maximizes its profits $\left(\pi_{i j}\right)$. As we cannot observe the profit directly, we further assume that the number of greenfield manufactures in each province $\left(y_{j}\right)$ is a function of the observable location characteristics $\left(x_{j}\right)$ of that province. Following Tokunaga and Akune [25] and Coughlin and Segev [5], we can express the negative binomial model (Greene [10]) ${ }^{3}$ as follows:

$$
\ln E\left(y_{j}\right)=\beta^{\prime} x_{j}+\varepsilon_{j}
$$

where $y_{j}$ is the number of location for Japanese manufactures in province $j$ per year, $\beta^{\prime}$ is a parameter vector, $x_{j}$ is a provincial characteristics vector, and $\varepsilon_{j}$ is a disturbance vector. The density function of $y_{i}$ can be represented as

$$
f\left(y_{j} \mid x_{j}\right)=\frac{\theta^{\theta}\left(e^{\beta^{\prime} x_{j}}\right)^{y_{j}} \Gamma\left(\theta+y_{j}\right)}{\Gamma\left(y_{j}+1\right) \Gamma(\theta)\left(e^{\beta^{x_{j}}}+\theta\right)^{\theta+y_{j}}}
$$

We use equation (2) to estimate the parameter $\beta$. Because equation (2) is a nonlinear equation, maximum likelihood is employed in estimation.

\subsection{Data Sources and Model Specification}

The data employed in this paper are disaggregated firm-level Japanese FDI data which come from a "Cyugoku Sinsyutsu Kigyou Ichiran 2003-2004" (A view of Japanese Overseas Affiliates in China 2003-2004) which is compiled by the 21st Century China Research Institute. Our estimation data is new Japanese plants location data established from 1992 to 2003 (372 pooling data), following the view that Japanese electronics FDI has been increasing after Mr. Deng Xiaoping's 1992 speech during his tour to the south. In location choice model of plants for each province in China, the dependent variable is the number of Japanese manufacturing establishments in each province in China.

We obtain data of the provincial characteristics in China from Comprehensive Statistical Data and Material on 50 Years of New China (from 1992 to 1998), China Statistical Yearbook 1999-2003 (National Bureau of Statistics People's Republic of China), and China's Association of Development Zones. In this model, the independent variables are given in Table 2.

1. Market potential Market potential is considered as an important determinant as shown in Figure 3. Market potential (lnMP) measures both demand potentials and economies of scale. Recently some new studies are analyzing the effects of market potential on the location of foreign firms [e.g. Redding and Venables [20], [21], Head and Mayer [14]]. They provide evidence that the geography of market access and supply access is statistically significant and quantitatively important. Since there is quite differences in the area of provinces in China, with mean 305,630 square kilometers, and standard deviation of 37.41, we divide provincial market potential and GDP by the area of corresponding province, and use the logarithm of provincial market potential divided by area, $\operatorname{lnMP}$ as the market potential variable ${ }^{4}$.

2. Wage In China, wage rate (WAGE) is highly ranked in Figure 3. As the wage rate is an important factor for Japanese investment for electronics industry in China, we assume that the real wage is an important determinant. We use logarithm of provincial average real wages of staff and workers (lnWAGE) as wage variable.

3. Labor quality Labor quality has the positive impact of location choice because Japanese firms tend to seek a higher quality labor ( $\mathrm{He}[13])$. We therefore use logarithm of provincial number of scientific and technical persons in state owned enterprises (lnLABQ) as labor quality variable. $^{5}$ 
Table 2 Descriptions of Variables and Expected Signs

\begin{tabular}{|c|c|c|}
\hline Variables & Descriptions & $\begin{array}{l}\text { Expected } \\
\text { Signs }\end{array}$ \\
\hline Location choice & $\begin{array}{l}\text { Number of Japanese electronics greenfield manu- } \\
\text { factures in a province, (number) }\end{array}$ & \\
\hline Market potential (lnMP) & $\begin{array}{l}\text { Logarithm of provincial market potential/area, } \\
\text { (108 yuan/square kilometer) }\end{array}$ & + \\
\hline Wage (lnWAGE) & $\begin{array}{l}\text { Logarithm of provincial average real wages of staff } \\
\text { and workers, (yuan) }\end{array}$ & - \\
\hline Labor quality (lnLABQ) & $\begin{array}{l}\text { Logarithm of provincial number of scientific and } \\
\text { technical person in state owned enterprises, (num- } \\
\text { ber) }\end{array}$ & + \\
\hline Infrastructure (lnINFRA) & $\begin{array}{l}\text { Logarithm of provincial highway density, (kilo- } \\
\text { meter/square kilometer) }\end{array}$ & + \\
\hline Policy incentives (POLI) & $\begin{array}{l}\text { Provincial number of special economic zones, open } \\
\text { coastal cities and national-level development } \\
\text { zones, (number) }\end{array}$ & + \\
\hline $\begin{array}{l}\text { Japanese manufactures } \\
\text { agglomeration (lnAGGLO1) }\end{array}$ & $\begin{array}{l}\text { Logarithm of (provincial number of Japanese } \\
\text { manufactures to previous year }+1 \text { ), (number) }\end{array}$ & + \\
\hline $\begin{array}{l}\text { Electronics manufactures } \\
\text { agglomeration (lnAGGLO2) }\end{array}$ & $\begin{array}{l}\text { Logarithm of (provincial number of electronics } \\
\text { manufacturers to previous year }+1 \text { ), (number) }\end{array}$ & + \\
\hline $\begin{array}{l}\text { Japanese electronics } \\
\text { manufactures agglomeration } \\
(\ln A G G L O 3)\end{array}$ & $\begin{array}{l}\text { Logarithm of (provincial number of Japanese elec- } \\
\text { tronics manufacturers to previous year }+1 \text { ), (num- } \\
\text { ber) }\end{array}$ & + \\
\hline $\begin{array}{l}\text { Japanese electronics } \\
\text { manufactures Keiretsu } \\
\text { agglomeration (lnAGGLO4) }\end{array}$ & $\begin{array}{l}\text { Logarithm of (provincial number of Japanese elec- } \\
\text { tronic manufactures invested by core firms to previ- } \\
\text { ous year }+1) \text {, (number) }\end{array}$ & + \\
\hline
\end{tabular}

Note: GDP and wage are real values at $1992=100$.

Table 3 Correlation Matrix of Independent Variables

\begin{tabular}{|c|c|c|c|c|c|c|c|c|c|}
\hline & MP & WAGE & LABQ & INFRA & POLI & AGGLO1 & AGGLO2 & AGGLO3 & AGGLO4 \\
\hline MP & 1.000 & & & & & & & & \\
\hline WAGE & 0.335 & 1.000 & & & & & & & \\
\hline LABQ & 0.135 & -0.164 & 1.000 & & & & & & \\
\hline INFRA & 0.832 & 0.234 & 0.503 & 1.000 & & & & & \\
\hline POLI & 0.290 & 0.432 & 0.349 & 0.425 & 1.000 & & & & \\
\hline AGGLO1 & 0.615 & 0.442 & 0.512 & 0.687 & 0.725 & 1.000 & & & \\
\hline AGGLO2 & 0.554 & 0.118 & 0.774 & 0.760 & 0.664 & 0.829 & 1.000 & & \\
\hline AGGLO3 & 0.561 & 0.525 & 0.353 & 0.573 & 0.755 & 0.895 & 0.729 & 1.000 & \\
\hline AGGLO4 & 0.443 & 0.554 & 0.208 & 0.439 & 0.595 & 0.718 & 0.538 & 0.870 & 1.000 \\
\hline
\end{tabular}

4. Infrastructure The level of infrastructure is measured by logarithm of provincial highway density (InINFRA).

5. Policy incentives We use provincial number of special economic zones, open coastal cities and national-level development zones (POLI) as Policy incentives variable.

6. Agglomeration effects If Japanese electronic firms locate close to one another in China, the industrial agglomeration helps to expand their sales and to save transportation cost, that is 
agglomeration economies (Marshall [19], Krugman [18], Fujita, Krugman, and Venables [7], Fujita and Thisse [8], and Tokunaga and Ishii [27]). Hence, we set up the hypothesis that industrial agglomeration plays an important role in location choice behavior of Japanese electronics firms in China. We use four kinds of agglomeration variables: (1) Japanese manufactures agglomeration (lnAGGLO1), (2) electronics manufactures agglomeration (lnAGGLO2), (3) Japanese electronics manufactures agglomeration (lnAGGLO3), and (4) Japanese electronics manufactures keiretsu agglomeration (InAGGLO4) in order to test agglomeration effects on the location choice at provincial level.

Table 3 reports the correlation coefficient matrix among independent variables. All correlation coefficients are lower except correlation coefficient between market potential and infrastructure.

\section{Estimation Results}

The results of the negative binomial estimation are presented in Table 4 for the new plant location choice model. In order to test the hypothesis that agglomeration effects play an important role in location choice of Japanese manufacturers in China, we totally considered five different variations of this model. With a few exceptions, the estimation results support the major hypotheses.

For some traditional location factors, the coefficient estimates for the real manufacturing wages variables (WAGE) are negative and statistically significant at the 0.01 level in all cases. This result suggests that new Japanese electronics manufactures tend to choose locations with a low real wage cost. The coefficient estimates for the labor quality variables (LABQ) are positive and statistically significant at the 0.01 level in all cases, implying that new Japanese electronics manufactures are inclined to choose locations of high quality labor forces. The coefficient estimates of infrastructure (INFRA) are also positive and almost statistically significant at the 0.1

Table 4 Results of the new plant location choice model in China (Negative Binominal Model)

\begin{tabular}{|c|c|c|c|c|c|}
\hline & (1) & $(2)$ & (3) & (4) & $(5)$ \\
\hline Constant & $\begin{array}{c}-13.574^{* * *} \\
(-3.08)\end{array}$ & $\begin{array}{l}-5.271 \\
(-1.05)\end{array}$ & $\begin{array}{c}-10.562^{* *} \\
(-2.37)\end{array}$ & $\begin{array}{l}-3.437 \\
(-0.68)\end{array}$ & $\begin{array}{l}-9.561^{*} \\
(-1.91)\end{array}$ \\
\hline $\operatorname{lnMP}$ & $\begin{array}{l}0.820^{* * *} \\
(7.37)\end{array}$ & $\begin{array}{l}0.573^{* * *} \\
(4.48)\end{array}$ & $\begin{array}{l}0.488^{* * *} \\
(4.62)\end{array}$ & $\begin{array}{l}0.700^{* * *} \\
(6.35)\end{array}$ & $\begin{array}{l}0.819 * * * \\
(7.32)\end{array}$ \\
\hline $\operatorname{lnWAGE}$ & $\begin{array}{c}-1.297^{* * *} \\
(-3.44)\end{array}$ & $\begin{array}{l}-1.600^{* * *} \\
(-4.19)\end{array}$ & $\begin{array}{l}-1.147^{* * *} \\
(-3.24)\end{array}$ & $\begin{array}{l}-1.746^{* * *} \\
(-4.49)\end{array}$ & $\begin{array}{l}-1.624^{* * *} \\
(-3.79)\end{array}$ \\
\hline $\operatorname{lnLABQ}$ & $\begin{array}{l}1.371^{* * *} \\
(5.58)\end{array}$ & $\begin{array}{l}0.905^{* * *} \\
(3.26)\end{array}$ & $\begin{array}{l}0.686^{* * *} \\
(2.587)\end{array}$ & $\begin{array}{l}0.959 * * * \\
(3.69)\end{array}$ & $\begin{array}{l}1.281^{* * *} \\
(5.13)\end{array}$ \\
\hline lnINFRA & $\begin{array}{l}0.805^{* *} \\
(2.09)\end{array}$ & $\begin{array}{l}0.693 * * \\
(1.82)\end{array}$ & $\begin{array}{l}0.512 \\
(1.33)\end{array}$ & $\begin{array}{l}0.442 \\
(1.14)\end{array}$ & $\begin{array}{c}0.740^{*} \\
(1.89)\end{array}$ \\
\hline POLI & $\begin{array}{l}0.411^{* * *} \\
(10.7)\end{array}$ & $\begin{array}{l}0.325^{* * *} \\
(7.25)\end{array}$ & $\begin{array}{l}0.072 \\
(1.19)\end{array}$ & $\begin{array}{l}0.335^{* * *} \\
(8.15)\end{array}$ & $\begin{array}{l}0.408^{* * *} \\
(10.6)\end{array}$ \\
\hline lnAGGLO1 & & $\begin{array}{l}0.411 * * * \\
(3.21)\end{array}$ & & & \\
\hline lnAGGLO2 & & & $\begin{array}{l}1.357 * * * \\
(6.39)\end{array}$ & & \\
\hline lnAGGLO3 & & & & $\begin{array}{l}0.435^{* * *} \\
(4.07)\end{array}$ & \\
\hline lnAGGLO4 & & & & & $\begin{array}{c}0.154^{*} \\
(1.69)\end{array}$ \\
\hline Observations & 372 & 372 & 372 & 372 & 372 \\
\hline Log likelihood & -372.48 & -367.13 & -351.48 & -363.92 & -371.01 \\
\hline
\end{tabular}


level. Furthermore, the coefficient estimates of Policy incentives (POLI) are also positive and almost statistically significant at the 0.01 level.

Next, we examine the hypothesis that market potential and industrial agglomeration play an important role in location choice of Japanese manufacturers in China. Both market potential and industrial agglomeration variables are positive and statistically significant at the 0.01 level except AGGLO4. The coefficient estimate of market potential (MP) is positive and statistically significant at the 0.01 level in all cases, implying that new Japanese electronics manufactures tend to choose locations with wider provincial's market potential since large market access gives opportunities to use domestic scale economies and consequently low cost of production (Krugman [18]).

The coefficient estimate of Japanese manufactures agglomeration (AGGLO1) is positive and statistically significant at the 0.01 level, suggesting that new Japanese electronics manufactures tend to choose locations favored by Japanese manufactures. The coefficient estimate of electronics manufactures agglomeration (AGGLO2) is positive and statistically significant at the 0.01 level, implying that new Japanese electronics plants tend to choose locations favored by electronics manufactures. The coefficient estimate of Japanese electronics manufactures agglomeration (AGGLO3) is positive and statistically significant at the 0.01 level, implying that new Japanese electronics plants tend to choose locations favored by Japanese electronics manufactures. The coefficient estimate of Japanese electronics manufactures keiretsu agglomeration (AGGLO4) is positive and statistically significant at the 0.1 level, implying that new Japanese electronics manufactures tend to choose locations where there are keiretsu's plants of Japanese electronics firms.

Thus, we find that market potential and industrial agglomeration effects play an important role in location choice of Japanese manufacturers in China.

\section{Conclusion}

In this paper, we examined the hypothesis that agglomeration effects play an important role in location choice behavior of Japanese electronics firms in China, according to Krugman [18], Fujita and Krugman [6], Fujita, Krugman, and Venables [7]. Using the data of Cyugoku Sinsyutsu Kigyou Ichiran 2003-2004 (A view of Japanese Overseas Affiliates in China 2003-2004), we estimated a location choice model of Japanese electronics firms using market potential, industrial agglomeration, and traditional factors such as wage, infrastructure, and policy incentives as explanatory variable. From the results of this estimation, we found that agglomeration effects play an important role in location choice behaviors of Japanese electronics firms in China.

In order to examine these issues in more detail, further studies are required. One is a further study of agglomeration effects using data of city in China. Another possible study is a comparative study among Japanese electronics industry and other industries such as machinery, food processing, and transportation equipment.

\section{Endnotes}

1. Jin and Tokunaga [17] found that agglomeration effects of Chinese food manufactures and Japanese keiretsu had positive effects on location decisions of the Japanese food industry in China.

2. The database of Japanese electronics industry investment in Chinese provinces is from Cyugoku Sinsyutsu Kigyou Ichiran 2003-2004 (Japanese enterprises investment in China 20032004).

3. See Greene [10]. The density function of $y_{i}$ can be represented as follows: Let $\beta^{\prime} x_{j}=\ln \lambda_{j}$ and $\varepsilon_{j}=\ln u_{j}$, equation (1) can be written as $\ln E\left(y_{j}\right)=\ln \lambda_{j}+\ln u_{j}$ (A.1). Then the distribution of $y_{i}$ conditioned on $x_{i}$ and $u_{i}\left(i . e ., \varepsilon_{i}\right)$ remains Poission with conditional mean and variance $\mu_{i}$, 


$$
f\left(y_{j} \mid x_{j}, u_{j}\right)=\frac{e^{-\lambda_{j} u_{j}}\left(\lambda_{j} u_{j}\right)^{y_{j}}}{y_{j} !} .
$$

As the unconditional distribution $f\left(y_{j} \mid x_{j}\right)$ is the expected value of $f\left(y_{j} \mid x_{j}, u_{j}\right)$, the density function of $y_{i}$ is

$$
\begin{aligned}
& f\left(y_{j} \mid x_{j}\right)=\int_{0}^{\infty} \frac{e^{-\lambda_{j} u_{j}}\left(\lambda_{j} u_{j}\right)^{y_{j}}}{y_{j} !} \frac{\theta^{\theta} e^{-\theta u_{j}} u_{j}^{\theta-1}}{\Gamma(\theta)} d u_{j}=\frac{\Gamma\left(\theta+y_{j}\right)}{\Gamma\left(y_{j}+1\right) \Gamma(\theta)} r_{j}^{y_{j}}\left(1-r_{j}\right)^{\theta}, \\
& \text { where } \quad r_{j}=\frac{\lambda_{j}}{\lambda_{j}+\theta} .
\end{aligned}
$$

The distribution has conditional mean $\lambda_{j}$ and conditional variance $\lambda_{j}(1+(1 / \theta)) \lambda_{j}$. Substituting $\lambda_{j}=e^{\beta x_{j}}$ into equation (A.1), we have the density function of $y_{i}$

$$
f\left(y_{j} \mid x_{j}\right)=\frac{\theta^{\theta}\left(e^{\beta^{\prime} x_{j}}\right) y_{i} \Gamma\left(\theta+y_{j}\right)}{\Gamma\left(y_{j}+1\right) \Gamma(\theta)\left(e^{\beta x_{j}}+\theta\right)^{\theta+y_{j}}} .
$$

4. Enlightened from Harries [12], we define market potential for province $j$ as:

$$
M P_{j}=\sum_{i=1}^{n} \exp _{i} / d_{i j}
$$

where $\exp _{i}$ is per capita annual living expenditure of Urban Residents by province $j . \quad d_{i j}$ is the distance from provincial $i$ to province $j$, for $i \neq j$.

For $i=j$, following Head and Mayer [14], We assume that the distance from a region to itself is obtained using a simple geographical approximation and that each region is approximated as a disk all production concentrates at the center and consumers are uniformly distributed throughout the rest of the area. The average distance between a producer and a consumer is then given by

$$
d_{i j}=\int_{0}^{R} r \frac{2 r}{R^{2}} d r
$$

where $R$ denotes the radius of the disk, and $\frac{2 r}{R^{2}}$ is the density of consumer at any given distance $r$ to the center. We obtain :

$$
d_{i j}=\frac{2}{3} R=\frac{2}{3} \sqrt{A / \pi}
$$

where $A$ is the area of the region.

5. We used the provincial number of scientific and technical person in state owned enterprise as labor quality variables due to data availability, but there is a negative correlation between real wage and labor quality variables, we want to improve it as future work.

\section{Acknowledgements}

This paper was presented at the Annual Meeting of the Japan Section of the Regional Science Association International (JSRSAI), Oct. 8-10, 2005, University of Tottori, Japan. We are grateful to two anonymous referees for their useful comments and insight. This research was financially supported by the Grants-in-Aid of Japan Society for the Promotion of Science (JSPS) in the fiscal year 2004 and 2006.

\section{References}

[1] Belderbos, R. and Carree, M., "The location of Japanese investments in China: Agglomeration effects, Keiretsu, and firm heterogeneity," Journal of the Japanese and International Economies, 16 (2), 2002, pp. 194-211.

[2 $]$ Broadman, H.G. and Sun, X., "The distribution of foreign direct investment in China," World Economy, 20 (3), 1997, pp. 339-361. 
[3] Cheng, L.K. and Kwan, Y.K., "What are the determinants of the location of foreign direct investment? The Chinese experience," Journal of International Economics, 51(2), 2000, pp. 379400 .

[ 4 ] Chyau T. and Ng, L., "Manufacturing agglomeration as incentives to Asian FDI in China after WTO," Journal of Asian Economics, 15, 2004, pp. 673-693.

[5] Coughlin, C. and Segev, E., "Foreign direct investment in China : A spatial econometric study," World Economy, 23(1), 2000, pp. 1-23.

[6] Fujita, M. and Krugman, P., "When is the economy monocentric ? Von Thiunen and Chamberlin unified,” Regional Science and Urban Economics, 25(4), 1995, pp. 508-528.

[7] Fujita, M., Krugman, P. and Venables, A., The spatial economy : Cities, Regions, and International Trade, Cambridge, MA : MIT Press, 1999.

[8] Fujita, M. and Thisse, A., Economics of agglomeration, Cambridge University, 2002.

[ 9 ] Fukao, K. and Yue, X., "The Locational Selection of Japanese Electronics Firms," Mita Journal of Economics, 90, 1997, pp. 11-39.

[10] Greene, W., Econometric analysis, Prentice-Hall, 2000.

[11] Hanson, G., Market potential, increasing returns, and geographic concentration, University of California, San Diego, manuscript, 2001.

[12] Harris, C., "The market as a factor in the localization of industry in the United States," Annals of the Association of American Geographers, 44, 1954, pp. 315-48.

[13] He, C., "Location of foreign manufacturers in China: Agglomeration economies and country of origin effects," Papers in Regional Science, 82 (3), 2003, pp. 351-372.

[14] Head, K. and Mayer, T., "Market Potential and the Location of Japanese Investment in Europe," Review of Economics and Statistics, 86(4), 2004, pp. 959-972.

[15] Head, K. and Ries, J., "Inter-city competition for Foreign investment: Static and dynamic effects of China's incentive areas,” Journal of Urban Economics, 40 (1), 1996, pp. 38-60.

[16] Head, K., Ries, J. and Swenson, D., "Attracting foreign manufacturing: Investment promotion and agglomeration,” Regional Science and Urban Economics, 29 (2), 1999, pp. 197-218.

[17] Jin, S. and Tokunaga, S., "Japanese Food Industry Investment in China : Location Choice and Agglomeration Effects," the Special Issue of the Journal of Rural Economics, 2005, pp. 493-498.

[18] Krugman, P., Geography and Trade, Cambridge, MA: MIT Press, 1991.

[19] Marshall, A., Principles of Economics, London: Macmillan and Co., Ltd., 1920.

[20] Redding, S. and Venables, A., "Economic geography and international inequality," CEPR working paper, No. 2568, 2000.

[21] Redding, S. and Venables, A., "Economic geography and international inequality," Journal of International Economics, 62 (1), 2004, pp. 53-82.

[22] Smith, D. and Florida, R., "Agglomeration and Industrial Location : An Econometric Analysis of Japanese-Affiliated Manufacturing Establishments in Automotive-Related Industries,” Journal of Urban Economics, 36, 1994, pp. 23-41.

[23] Sun, Q., Tong, W. and Yu, Q., “Determinants of foreign direct investment across China,” Journal of International Money and Finance, 21(1), 2002, pp. 79-113.

[24] Togo, K. and Arikawa, Y., "Agglomeration Effects vs. Policy Effects: The Case of the Electronics Industry in Malaysia,” Asian Economic Journal, 16 (3), 2002, pp. 229-245.

[25] Tokunaga, S. and Akune, Y., "Industrial Agglomeration and the location of Foreign Direct Investment for Japanese Electronics Industry in East Asia," Studies in Regional Science, 33 (3), 2003, pp. 37-48.

[26] Tokunaga, S. and Ishii, R., Agglomeration and Industrial location: Empirical Analysis of Location Choice of Japanese Multinational Firms in East Asia, Paper presented at the annual meeting of the Japan Association of Economics and Econometrics, September 23-24, Japan, 1995.

[27] Tokunaga, S. and Ishii, R., An empirical analysis of agglomeration effects and locational choice 
of Japanese electronics firms in East Asia, in Hirotada Kohno, Peter Nijkamp \& Jacques Poot (eds), Regional Cohesion and Competition in the Age of Globalization, 2000, pp. 127-143.

[28] Wakasugi, R., "The Effects of Chinese Regional Conditions on the Location Choice of Japanese Affiliates," The Japanese Economic Review, 56(4), 2005, pp. 390-407.

[29] Zhang, L., "Location-specific advantages and manufacturing direct foreign investment in south China,” World Development, 22 (1), 1994, pp. 43-53. 